\title{
A NEW SPECIES OF ACMELLA (GASTROPODA: ASSIMINEIDAE) FROM PENINSULAR MALAYSIA
}

\author{
JUNN KITT FOON ${ }^{1,2,3 *}$, MOHAMMAD EFFENDI MARZUKI ${ }^{4,5}$ \\ ${ }^{1}$ Institute for Tropical Biology and Conservation, Universiti Malaysia Sabah, Jalan UMS, 88400, \\ Kota Kinabalu, Malaysia (e-mail: jkfoon.research@gmail.com); (10 https://orcid.org/0000-0001-7876-8384 \\ 2 Project Limestone, Rimba, Malaysia \\ ${ }^{3}$ Australian Museum Research Institute, Australian Museum, Australia \\ ${ }^{4}$ Institute of Biodiversity and Environmental Conservation, Universiti Malaysia Sarawak, Malaysia \\ ${ }^{5}$ Jalan Muut, Kampung Sekaan Besar, Malaysia \\ *corresponding author
}

ABSTRACT: A new species Acmella paeninsularis from the limestone hills of Perak, Peninsular Malaysia is described based on an ample material. Its diagnostic characters in comparison with related species are given.

KEY WORDS: land snail; Peninsular Malaysia; limestone hills; karst; taxonomy

Publication LSID urn:lsid:zoobank.org:pub:CFB28BF9-3F47-47BA-8F9F-4D34340C07B3

\section{INTRODUCTION}

The genus Acmella was erected to accommodate Acmella tersa (Benson, 1853) from Assam, India (BLANFORD 1869). DAS et al. (2021) redescribed the type species $A$. tersa as possessing a shell with a finely granulose protoconch, somewhat pronounced wavy radial sculpture and elongate-ovoid aperture. THIELE (1931) diagnosed the genus as having a minute shell, tall spire, with curved radial sculpture on the whorls and a small, ovoid aperture. VERMEULEN et al. (2015) treated Acmella species in Sabah, Malaysian Borneo, which can be diagnosed as having a slight periomphalic thread that starts on the columellar side of the peristome and spirals steeply upwards, and a generally thin peristome. Two informal groups were distinguished: Group 1 has predominantly radial sculpture on the whorls; Group 2 has predominantly spiral sculpture, or radial and spiral sculpture about equally strong, or no sculpture at all. The new species described herein and those in Group 1 of VERMEULEN et al. (2015) are probably typical of Acmella, whereas all other species currently assigned to the genus may belong to other genera pending a genus-wide revision (DAS et al. 2021).
In Sundaland and adjacent regions, Acmella has hitherto been reported from Borneo (VERMEULEN et al. 2015, PHUNG et al. 2017, MARZUKI et al. 2021), Sumatra (MAASSEN 2000), Sumba (VAN BENTHEMJUtTING 1958), the Philippines (AUfFENBERG \& PÁll-Gergely 2020), Vietnam (VERMEULEN et al. 2019), Thailand (WANGKIRI et al. 2018), Laos (INKHAVILAY et al. 2019) as well as the Andaman and Nicobar Islands (GODWIN-AUSTEN \& NEVILL 1879, GODWIN-AUSTEN 1895, SUBBA RAO \& MitRA 1991). In Peninsular Malaysia, MAASSEN (2001) reported $A$. roepstorffiana Nevill, 1878 from Pahang. However, this record is doubtful and needs to be checked considering that $A$. roepstorffiana was previously described and known only from Katchal, Nicobar Islands (India), $1,000 \mathrm{~km}$ northwest of Pahang (GODWIN-AUSTEN \& NeVILl 1879). Here, we describe a new species of Acmella from the limestone karsts of Peninsular Malaysia. 


\section{MATERIAL AND METHODS}

The materials examined were obtained from leaf litter during the Perak limestone malacofauna survey of FOON et al. (2017). These materials are deposited in the BORNEENSIS collection (BOR/MOL), Institute for Tropical Biology and Conservation, Universiti Malaysia Sabah. Additional materials from the second author's collection (ME) were also examined. To ensure unambiguous reference to the localities of the examined materials, we provide the unique code numbers, names and coordinates of limestone outcrops derived from the Malaysian limestone karst database, Mykarst 2.0 (LIEW et al. 2021a, 2021b, 2021c, 2021d, 2021e).

This study is based on shell characters only. The holotype (BOR/MOL 9839) and seven paratypes (1 shell in BOR/MOL 9781, 1 shell in BOR/MOL 12502 , 5 shells in BOR/MOL 10453) of the new species were photographed and measured with a Leica DFC495 Digital Microscope Camera mounted on a Leica M205C microscope. Next, the holotype was gold-dusted and viewed under high vacuum with a Scanning Electron Microscope (JEOL JSM-5610LV, JEOL Ltd., Tokyo) to reveal the shell microsculpture.

Measurements of shell height (SH), shell width $(\mathrm{SW})$, aperture height $(\mathrm{AH})$, aperture width (AW) and number of ribs per $\mathrm{mm}$ were taken for the holotype (largest specimen among materials examined) and seven paratypes. The whorl counting (NW) followed Vermeulen \& WhitTEN (1998). The new species is described and compared with illustrations and descriptions of its congeners in BENSON (1853), BLANFORD (1869), GODWIN-AUSTEN \& NEVILL (1879), GODWIN-AUSTEN (1895), VAN BENTHEMJUTTING (1958), MAASSEN (2000), VERMEULEN \& JUNAU (2007), VERMEULEN et al. (2015), PHUNG et al. (2017), WANGKIRI et al. (2018), VERMEULEN et al. (2019), INKHAVILAY et al. (2019), AUfFENBERG \& PÁll-Gergely (2020), PÁll-Gergely (2020), DAS et al. (2021), MARZUKI et al. (2021) and references therein.

\section{SYSTEMATIC PART}

Family Assimineidae Adams et Adams, 1856 Genus Acmella Blanford, 1869

Acmella paeninsularis sp. nov.

Figs 1-5

urn:Isid:zoobank.org:act:23C4B15B-B8C2-4EA7-8468-B1E6CD499303

Acmella 'Kanthan 1' Foon et al. 2017: 10-11, fig. 4A; PHUNG et al. 2018: table 1.

Examined material. Holotype, Malaysia, Peninsular Malaysia, State of Perak: mykarst-781, formerly labelled as "mykarst-184 Bat Cave" in FoON et al. (2017) $\left(04^{\circ} 54.34^{\prime} \mathrm{N}, 1^{\circ} 1^{\circ} 08.83^{\prime} \mathrm{E}\right)$ (BOR/ MOL 9839). Paratypes, Malaysia, Peninsular Malaysia, State of Perak: mykarst-781, formerly labelled as "mykarst-184 Bat Cave" in Foon et al. (2017) $\left(04^{\circ} 54.34^{\prime} \mathrm{N}, 101^{\circ} 08.83^{\prime} \mathrm{E}\right) \quad(\mathrm{BOR} / \mathrm{MOL}$ 9781, 3 shells; BOR/MOL 12502, 1 shell); Prk 47 Kanthan $\quad\left(04^{\circ} 45.99 ' \mathrm{~N}, \quad 101^{\circ} 07.19^{\prime} \mathrm{E}\right) \quad$ (BOR/MOL 9079, 4 shells; BOR/MOL 9157, 19 shells); Prk 64 Bt Kepala Gajah $\left(05^{\circ} 07.52^{\prime} \mathrm{N}, 100^{\circ} 58.45^{\prime} \mathrm{E}\right)$ (BOR/ MOL 10192, 1 shell); Prk 23 G. Rapat $\left(04^{\circ} 33.23^{\prime} \mathrm{N}\right.$, $\left.101^{\circ} 07.84^{\prime} \mathrm{E}\right)$ (BOR/MOL 10237, 1 shell); Prk 36 Gua Datok $\left(04^{\circ} 37.63^{\prime} \mathrm{N}, 101^{\circ} 09.64^{\prime} \mathrm{E}\right)$ (BOR/MOL 10453, 59 shells); Prk 42 G. Bercham $\left(04^{\circ} 38.71^{\prime} \mathrm{N}\right.$, $\left.101^{\circ} 08.05^{\prime} \mathrm{E}\right)$ (BOR/MOL 10583, 21 shells; BOR/ MOL 12497, 1 shell; BOR/MOL 12498, 1 shell; BOR/ MOL 12503, 2 shells); Prk 53 Hill KF (0451.95'N, $\left.101^{\circ} 07.38^{\prime} \mathrm{E}\right)$ (BOR/MOL 10784, 5 shells); Prk 01 G. Tempurung $\left(04^{\circ} 24.39^{\prime} \mathrm{N}, 101^{\circ} 11.21^{\prime} \mathrm{E}\right)$ (BOR/ MOL 11397, 2 shells; BOR/MOL 12501, 2 shells). Malaysia, Peninsular Malaysia, State of Kelantan: Ktn 45 unnamed $\left(05^{\circ} 5.31^{\prime} \mathrm{N}, 102^{\circ} 13.17^{\prime} \mathrm{E}\right)$ (ME 2195, $>10$ shells); Ktn 109 part of G. Panjang $\left(04^{\circ} 48.71^{\prime} \mathrm{N}\right.$, $\left.101^{\circ} 58.58^{\prime} \mathrm{E}\right) \quad$ (ME 2196, 1 shell); mykarst-168 $\left(04^{\circ} 55.44^{\prime} \mathrm{N}, 102^{\circ} 10.64^{\prime} \mathrm{E}\right)$ (ME 2198, 3 shells). Malaysia, Peninsular Malaysia, State of Pahang: Phg 73 Bt Charas $\left(03^{\circ} 54.42^{\prime} \mathrm{N}, 103^{\circ} 08.81^{\prime} \mathrm{E}\right)$ (ME $634,>10$ shells); Phg 01 Kota Gelanggi $\left(03^{\circ} 53.63^{\prime} \mathrm{N}\right.$, $102^{\circ} 28.74^{\prime}$ E) (ME 633, 8 shells); Malaysia, Peninsular Malaysia, State of Kedah: Kdh 04 Gunung Keriang $\left(06^{\circ} 11.38^{\prime} \mathrm{N}, 100^{\circ} 19.88^{\prime} \mathrm{E}\right)$ (ME 9890, 1 shell).

Description. Dimensions (Table 1): height 0.94$1.35 \mathrm{~mm}$; width $0.80-1.10 \mathrm{~mm}$; height/width ratio 1.16-1.31; number of whorls 4-5. Shell minute, thin, opaque, translucent white or cream-coloured. Surface dull. Spire conical with rounded periphery, apex obtuse, whorls convex. Suture deep, slightly shouldered. Shell almost scalariform. Protoconch with numerous small pits. Teleoconch radial sculpture predominant: densely and regularly spaced (32-60 ribs per $1 \mathrm{~mm}$ ), prosocline ribs distinctly sinuous at the periphery, and below the periphery are as strong as above, rarely bifurcated from the periphery toward base. Spiral threads present but generally inconspicuous, somewhat densely and regularly spaced. Aperture obliquely elliptic in outline, parietal portion rather concave, 
transition from parietal portion to base rounded to obtusely angular. Aperture height $0.36-0.44 \mathrm{~mm}$; aperture width $0.37-0.51 \mathrm{~mm}$. Peristome thin, not expanded. Umbilicus open, narrow. Ratio of umbilicus width to shell width 0.13 .

Ecology. On limestone outcrops in primary and secondary forests.
Distribution. Known only from limestone karsts on the eastern and western lowlands of Peninsular Malaysia.

Diagnosis. A. paeninsularis shares the typical Acmella character of predominantly radial ribs that occasionally converge with four species: A. tersa (Benson, 1853), A. cyrtoglyphe Vermeulen, Liew et Schilthuizen, in VermeUlen et al. (2015), A. roepstorffiana

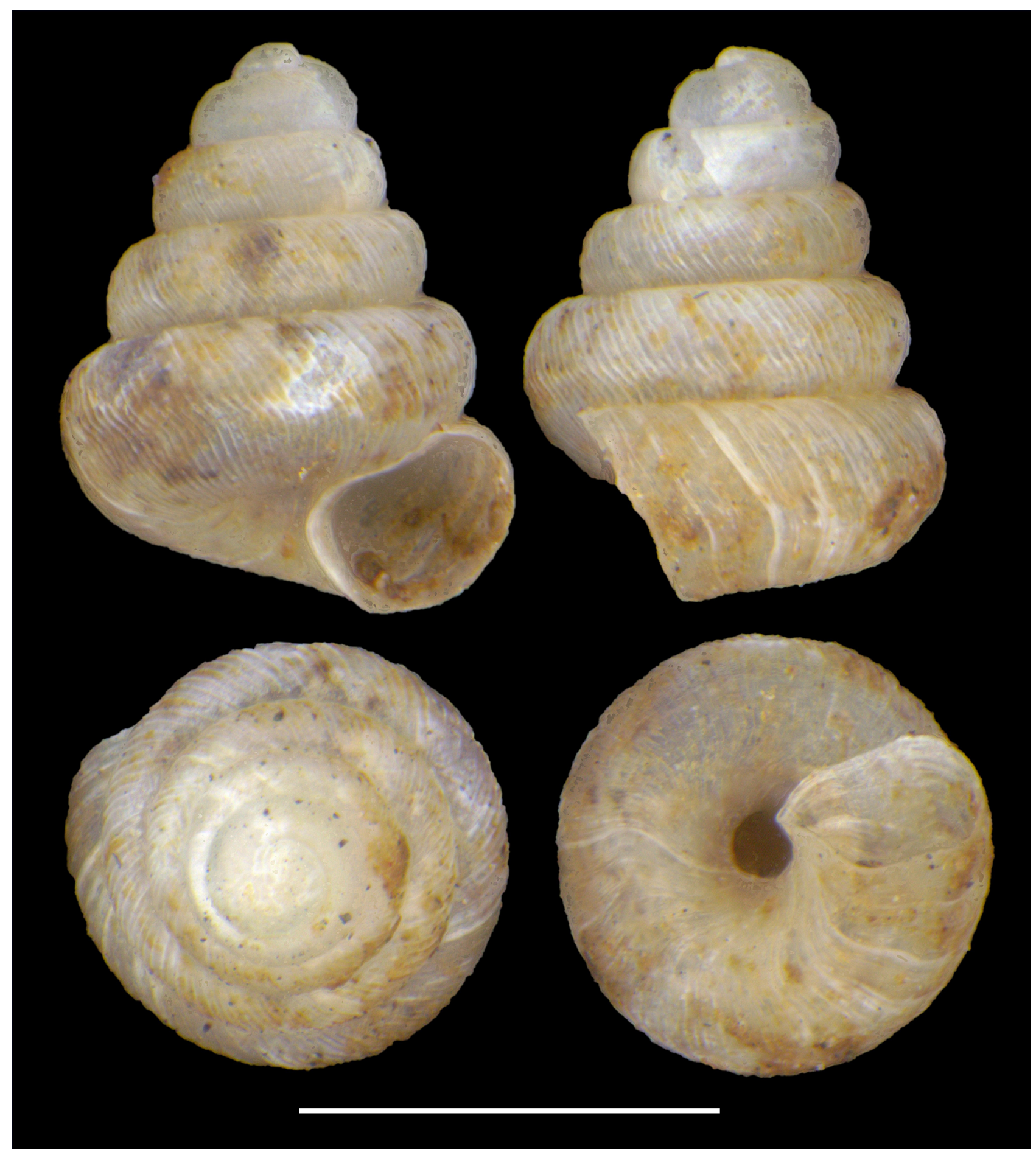

Fig. 1. Acmella paeninsularis sp. nov.: holotype (BOR/MOL 9839), from Peninsular Malaysia, State of Perak, mykarst-781. Scale bar $1 \mathrm{~mm}$ 


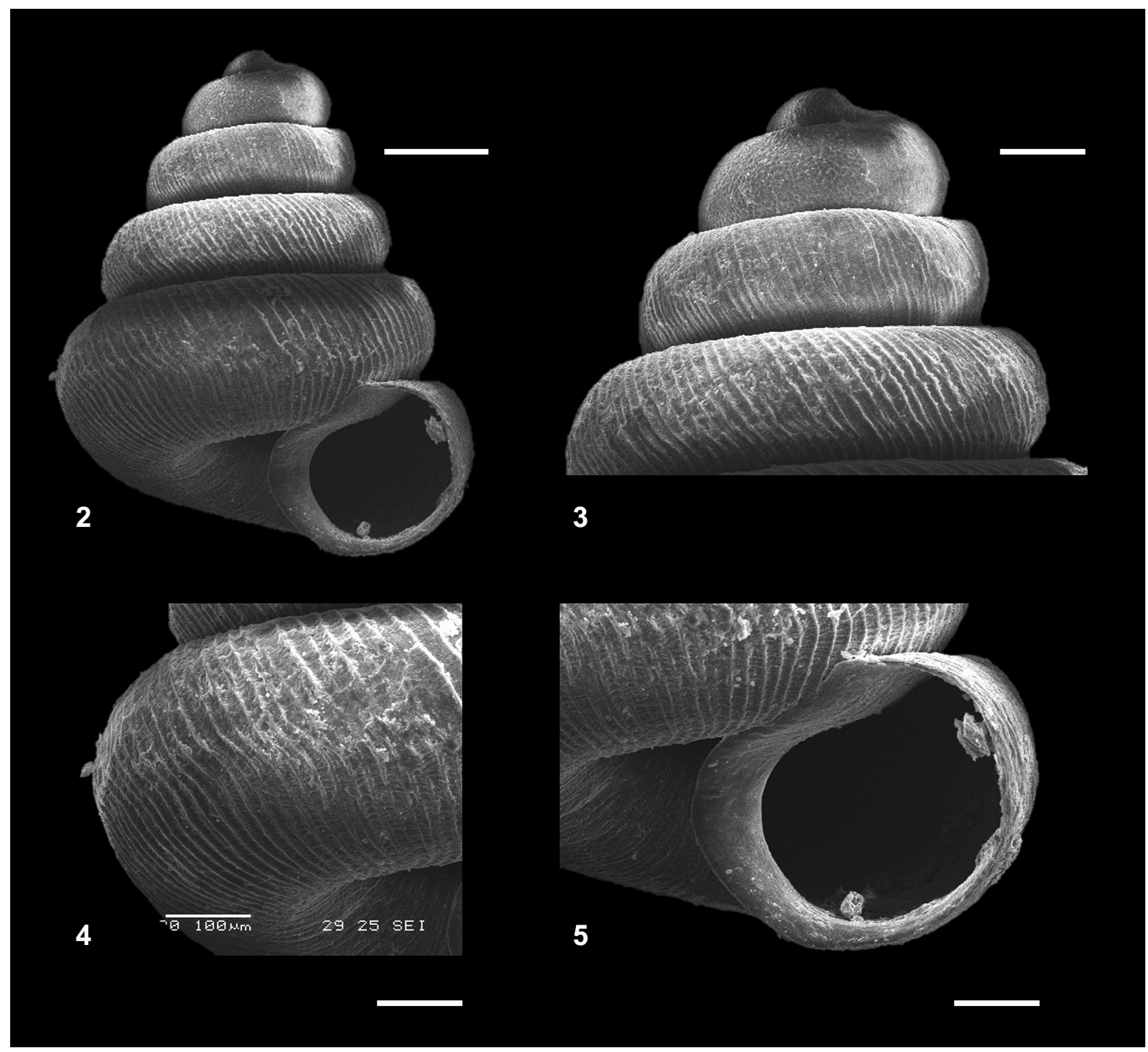

Figs 2-5. Various views of the holotype of Acmella paeninsularis sp. nov. (BOR/MOL 9839). SEM photo showing the shell and sculpture details: 2 - overview of the shell; 3 - protoconch and teleoconch view; 4 - penultimate whorl view; 5 aperture view. Scale bars $200 \mu \mathrm{m}(2)$ and $100 \mu \mathrm{m}(3-5)$

Nevill, 1878 and A. umbilicata Vermeulen, Liew et Schilthuizen, in VERMEULEN et al. (2015). A. paeninsularis is smaller, has a more conical shell and a wider umbilicus compared to $A$. tersa. The new species has a much narrower umbilicus compared to $A$. umbilicata. A. paeninsularis is most similar to the Bornean $A$. cyrtoglyphe and $A$. roepstorffiana from Katchal (India) in its shell size, dimensions and the prosocline radial ribs. It differs from $A$. cyrtoglyphe in having a more scalariform shell with a slight shoulder, a deeper suture and an umbilicus that is slightly obstructed by the peristome. A. paeninsularis differs from $A$. roepstorffiana in having a slight shoulder, deeper suture, taller spire and an umbilicus less obstructed by the peristome. A. paeninsularis has a simple peristome while that of $A$. roepstorffiana is thickened. A. paenin- sularis differs from all other non-typical Acmella species listed in DAS et al. (2021) in the presence of fine radial ribs.

Remarks. We placed this species in Acmella as it exhibits the typical Acmella character of predominant radial ribs that occasionally converge (DAS et al. 2021). The shells of $A$. paeninsularis also lack a spire constriction and the peristome is not thickened (VERMEULEN et al. 2015). A. paeninsularis belongs to Acmella Group 1 as defined by VERMEULEN et al. (2015). The record of A. roepstorffiana in Pahang (MAASSEN 2001) should be compared with $A$. paeninsularis to verify the identification.

Etymology. Named for Peninsular Malaysia, where the species occurs. 
Table 1. Shell measurements for Acmella paeninsularis sp. nov.

\begin{tabular}{|c|c|c|c|c|c|c|c|c|}
\hline Specimen & Locality & Shell height & Shell width & $\begin{array}{c}\text { Height / } \\
\text { width ratio }\end{array}$ & $\begin{array}{c}\text { Number } \\
\text { of } \\
\text { whorls }\end{array}$ & $\begin{array}{l}\text { Aperture } \\
\text { height }\end{array}$ & $\begin{array}{l}\text { Aperture } \\
\text { width }\end{array}$ & $\begin{array}{c}\text { Number } \\
\text { of ribs } \\
\text { per mm }\end{array}$ \\
\hline $\begin{array}{l}\text { BOR/MOL } \\
9839\end{array}$ & mykarst-781 & 1.35 & 1.10 & 1.23 & 5 & 0.44 & 0.51 & 38 \\
\hline $\begin{array}{l}\text { BOR/MOL } \\
9781\end{array}$ & mykarst-781 & 1.28 & 1.06 & 1.21 & 4.5 & 0.42 & 0.49 & 41 \\
\hline $\begin{array}{l}\text { BOR/MOL } \\
12502\end{array}$ & mykarst-781 & 1.00 & 0.85 & 1.17 & 4 & 0.39 & 0.39 & 41 \\
\hline $\begin{array}{l}\text { BOR/MOL } \\
10453 / 1\end{array}$ & $\begin{array}{c}\text { Prk } 36 \text { Gua } \\
\text { Datok }\end{array}$ & 1.01 & 0.82 & 1.23 & 4 & 0.38 & 0.40 & 43 \\
\hline $\begin{array}{l}\text { BOR/MOL } \\
10453 / 2\end{array}$ & $\begin{array}{c}\text { Prk } 36 \text { Gua } \\
\text { Datok }\end{array}$ & 1.04 & 0.80 & 1.30 & 4 & 0.37 & 0.40 & 41 \\
\hline $\begin{array}{l}\text { BOR/MOL } \\
10453 / 3\end{array}$ & $\begin{array}{c}\text { Prk } 36 \text { Gua } \\
\text { Datok }\end{array}$ & 1.05 & 0.80 & 1.31 & 4 & 0.39 & 0.40 & 32 \\
\hline $\begin{array}{l}\text { BOR/MOL } \\
10453 / 4\end{array}$ & $\begin{array}{c}\text { Prk } 36 \text { Gua } \\
\text { Datok }\end{array}$ & 0.95 & 0.81 & 1.17 & 4 & 0.37 & 0.39 & 43 \\
\hline $\begin{array}{l}\text { BOR/MOL } \\
10453 / 5\end{array}$ & $\begin{array}{l}\text { Prk } 36 \text { Gua } \\
\text { Datok }\end{array}$ & 0.94 & 0.81 & 1.16 & 4 & 0.36 & 0.37 & 60 \\
\hline $\begin{array}{l}\text { Range, mean } \\
\text { and standard } \\
\text { deviation (no. } \\
\text { of specimens) }\end{array}$ & & $\begin{array}{c}0.94-1.35 \\
1.08 \pm 0.15 \\
\quad(n=8)\end{array}$ & $\begin{array}{c}0.80-1.10 \\
0.88 \pm 0.12 \\
(n=8)\end{array}$ & $\begin{array}{c}1.16-1.31 \\
1.23 \pm 0.06 \\
(n=8)\end{array}$ & $\begin{array}{c}4-5 \\
\text { NA } \\
(n=8)\end{array}$ & $\begin{array}{c}0.36-0.44 \\
0.39 \pm 0.03 \\
\quad(n=8)\end{array}$ & $\begin{array}{c}0.37-0.51 \\
0.42 \pm 0.05 \\
\quad(n=8)\end{array}$ & $\begin{array}{l}32-60 \\
\text { NA } \\
(n=8)\end{array}$ \\
\hline
\end{tabular}

Measurements of shell height, shell width, aperture height and aperture width are in millimetres, NA - not acquired.

\section{ACKNOWLEDGEMENTS}

This study results from the first author's 20162019 work with Universiti Malaysia Sabah, partly supported by a grant from Kanthan Plant, Lafarge Malaysia Sdn. Bhd. (GL00154) and the Tony Whitten Conservation Prize 2019. This study was conducted with permits from the Department of Wildlife and Parks Peninsular Malaysia (JPHL\&TN(IP):100 34/1.24Jld 6(14)) and the Perak Forestry Department (PPN.PK 600/03/01Jld 9(62); AM-PM-202-16). We thank THOR-SENG LIEW and MOHD. AFIFI MOHD. NASIR for guidance on specimen deposition and SEM usage. We thank the anonymous reviewers for their constructive comments.

\section{REFERENCES}

ADAMS H., ADAMS A. 1854-1858. The genera of recent Mollusca 2. John van Voorst, London. https://doi.org/10.5962/bhl.title.4772

AuffenberG K., PÁll-Gergely B. 2020. Reassignment of three species and one subspecies of Philippine land snails to the genus Acmella Blanford, 1869 (Gastropoda: Assimineidae). Tropical Natural History 20: 223-227. https://li01.tci-thaijo.org/index.php/tnh/article/ view/243510

BENSON W. H. 1853. Additional character of the shell of the cyclostomatous genus Alycaus of Gray, with descriptions of its animal inhabitant, - of a fourth species, - and of other new Indian Cyclostomata; also, remarks on an unrecorded character in Diplommatina. The Annals and Magazine of Natural History, Ser. 2, 9: 283-287. https://doi.org/10.1080/03745485609495767

BENTHEM-JUTTING W. S. S. VAN 1958. Landmollusken von Sumba. Völkerkunde und des Naturhistorischen Museums in Basel 69: 90-117.

BLANFORD W. T. 1869. On the animal and operculum of Georissa, W. Blanf., and on its relations to Hydrocena, Parreys; with a note on Hydrocena tersa, Bens., and $H$. milium, Bens. The Annals and Magazine of Natural History, Ser. 4, 3: 173-179. https://doi.org/10.1080/00222936908695914

Das N. K., PÁll-Gergely B., Naggs F., Preece R. C., White T. S., ARAVIND N. A. 2021. Redescription of Acmella tersa (Benson, 1853), the type species of Acmella W. T. Blanford, 1869 (Gastropoda: Assimineidae), from Meghalaya, Northeast India. Molluscan Research 41: 324-331. https://doi.org/10.1080/13235818.2021.1991255

FOON J. K., ClemenTS G. R., LIEW T. S. 2017. Diversity and biogeography of land snails (Mollusca, Gastropoda) in the limestone hills of Perak, Peninsular Malaysia. ZooKeys 682: 1-94. https://doi.org/10.3897/zookeys.682.12999

GODWIN-AUSTEN H. H. 1895. List and distribution of the land-Mollusca of the Andaman and Nicobar Islands, 
with descriptions of some supposed new species. Proceedings of the Zoological Society of London 1895: 438-457.

https://www.biodiversitylibrary.org/page/30983429

Godwin-Austen H. H., NeviLl G. 1879. Descriptions of shells from Perak and the Nicobar Islands. Proceedings of the Zoological Society of London 1879: 734-740. https://doi.org/10.1111/j.1096-3642.1879.tb02710.x

INKHAVILAY K., SUTCHARIT C., BANTAOWONG U., CHANABUN R., SIRIWUT W., SRISONCHAI R., PHOLYOTHA A., JiRAPATRASILP P., PANHA S. 2019. Annotated checklist of the terrestrial molluscs from Laos (Mollusca, Gastropoda). ZooKeys 834: 1-166. https://doi.org/10.3897/zookeys.834.28800

LIEW T. S., FoON J. K., Clements G. R. 2021a. Conservation of limestone ecosystems of Malaysia. Part I. Acknowledgements, methodology, overview of limestone outcrops in Malaysia, references, detailed information on limestone outcrops of the states: Johor, Negeri Sembilan, Terengganu, Selangor, Perlis. Institute for Tropical Biology and Conservation, Universiti Malaysia Sabah, Kota Kinabalu. https://doi.org/10.6084/m9.figshare.14907846.v5

LIEW T. S., FoON J. K., ClemENTS G. R. 2021b. Conservation of limestone ecosystems of Malaysia. Part II. Detailed information on limestone outcrops of Perak. Institute for Tropical Biology and Conservation, Universiti Malaysia Sabah, Kota Kinabalu. https://doi.org/10.6084/m9.figshare.14907867.v5

LIEW T. S., FoON J. K., CLEMENTS G. R. 2021c. Conservation of limestone ecosystems of Malaysia. Part III. Detailed information on limestone outcrops of Kedah. Institute for Tropical Biology and Conservation, Universiti Malaysia Sabah, Kota Kinabalu.

https://doi.org/10.6084/m9.figshare.14907873.v5

LIEW T. S., FOON J. K., ClEMENTS G. R. 2021d. Conservation of limestone ecosystems of Malaysia. Part IV. Detailed information on limestone outcrops of Pahang. Institute for Tropical Biology and Conservation, Universiti Malaysia Sabah, Kota Kinabalu. https://doi.org/10.6084/m9.figshare.14907876.v5

LIEW T. S., FoON J. K., CLEMENTS G. R. 2021e. Conservation of limestone ecosystems of Malaysia. Part V. Detailed information on limestone outcrops of Kelantan. Institute for Tropical Biology and Conservation, Universiti Malaysia Sabah, Kota Kinabalu. https://doi.org/10.6084/m9.figshare.14907882.v5

MAASSEN W. J. M. 2000. Notes on the terrestrial molluscs of Sumatra, Indonesia, with descriptions of ten new species (Gastropoda, Prosobranchia \& Pulmonata). Basteria 64: 137-150.

https://natuurtijdschriften.nl/pub/597195

MAASSEN W. J. M. 2001. A preliminary checklist of the non-marine molluscs of West Malaysia. De Kreukel (extra edition 2001): 1-155.

MARZUKI M. E., LIEW T. S., MOHD-AZLAN J. 2021. Land snails and slugs of Bau limestone hills, Sarawak
(Malaysia, Borneo), with the descriptions of 13 new species. ZooKeys 1035: 1-113.

https://doi.org/10.3897/zookeys.1035.60843

NeviLL G. 1878. Hand list of Mollusca in the Indian Museum, Calcutta by Geoffrey Nevill. Part I. Gastropoda. Pulmonata and Prosobranchia-Neurobranchia. Office of superintendent of government printing, Calcutta. https://doi.org/10.5962/bhl.title.23978

PÁlL-GERGELY B. 2020. A new genus of Diplommatinidae from the Andaman Islands (Gastropoda: Caenogastropoda: Cyclophoroidea). Molluscan Research 40: 247250 .

https://doi.org/10.1080/13235818.2020.1786924

Phung C. C., Yong Y. Z., Mat SAID M. A., LieW T. S. 2018. Land snail fauna in Gunung Kuang Limestone Hill, Perak, Malaysia and its conservation implications (Mollusca, Gastropoda). ZooKeys 769: 1-11. https://doi.org/10.3897/zookeys.769.25571

PHUNG C. C., YU F. T. Y., LIEW T. S. 2017. A checklist of land snails from the west coast islands of Sabah, Borneo (Mollusca, Gastropoda). ZooKeys 673: 49-104. https://doi.org/10.3897/zookeys.673.12422

SubBA RAO N. V., Mitra S. C. 1991. Land molluscs of Andaman and Nicobar Islands. Records of the Zoological Survey of India, Occasional Paper no. 126: $1-88$.

http://faunaofindia.nic.in/PDFVolumes/occpapers/126/index.pdf

THIELE J. 1931. Handbuch der systematischen Weichtierkunde. Vol. 1, Part 2. Gustav Fischer, Jena.

Vermeulen J. J., JunAu D. J. 2007. Bukit Sarang (Sarawak, Malaysia), an isolated limestone hill with an extraordinary snail fauna. Basteria 71: 209-220. https://natuurtijdschriften.nl/pub/597351

Vermeulen J. J., Liew T. S., SChilthuizen M. 2015. Additions to the knowledge of the land snails of Sabah (Malaysia, Borneo), including 48 new species. ZooKeys 531: 1-139. https://doi.org/10.3897/zookeys.531.6097

Vermeulen J. J., LuU H. T., THEARY K., ANKer K. 2019. New species of land snails (Mollusca: Gastropoda: Caenogastropoda and Pulmonata) of the Mekong Delta limestone hills (Cambodia, Vietnam). Folia Malacologica 27: 7-41.

https://doi.org/10.12657/folmal.027.001

Vermeulen J. J., WhitTen A. J. 1998. Fauna Malesiana Guide to the land snails of Bali. Backhuys, Leiden.

WANGKIRI P., PANPONG S., JAIJAN N., EIAMSUM-ANG S., CHAIJIRA WONG R., WONGKHAMHEANG K., DUMRONGROJWATTANA P. 2018. First record of the microsnail genus Acmella (Gastropoda: Assimineidae) from Thailand. Burapha Science Journal 23: 1585-1596. http://science.buu.ac.th/ojs246/index.php/sci/article/ view/2271

Received: October 1st, 2021

Revised: December 20th, 2021

Accepted: February 3rd, 2022

Published on-line: March 1st, 2022 